\title{
Developments of low cost riverbank protection in Bangladesh
}

\author{
Knut Oberhagemann \\ Northwest Hydraulic Consultants Ltd., Canada \\ A.M. Aminul Haque \\ Bangladesh Water Development Board, Dhaka, Bangladesh
}

\begin{abstract}
Over the last two decades the Bangladesh Water Development Board (BWDB) has developed the widely accepted riverbank protection technology of geotextile bag revetments, consisting of multiple layers of systematically dumped geobags below low water plus a single layer of concrete blocks above low water. The original design characteristics from the early 2000s have proven sufficient for the most common application alongside largely agricultural land, with emphasis on the dimensions of the toe apron. In case of more severe design requirements, geotextile bags have been used as filter layer covered with rock. By and large geotextile bag revetments have become the backbone for a more stabilized Brahmaputra River System with a narrowed river corridor.
\end{abstract}

\section{FROM TOWN PROTECTION TO RIVER MANAGEMENT}

\subsection{The dynamic Bangladesh delta}

Bangladesh is being shaped by the Ganges and Brahmaputra rivers, which have formed one of the largest deltas in the world. The lower Brahmaputra, named Jamuna in Bangladesh, is the largest braided sand bed river of the world and averages $12 \mathrm{~km}$ width. After its confluence with the Ganges, the combined river named the Padma, together with the Congo ranks second in terms of annual average discharge (around $40,000 \mathrm{~m}^{3} / \mathrm{s}$ ) with a 100 -year flood of nearly $150,000 \mathrm{~m}^{3} / \mathrm{s}$ and a 500 -year flood of about $160,000 \mathrm{~m}^{3} / \mathrm{s}$ (Maunsell AECOM, 2011). The sediment load is estimated at around one billion tons annually (Delft Hydraulics \& Danish Hydraulic Institute, 1996). The river's bed and banks largely consist of fine, unconsolidated and poorly graded sands with traces of mica. Riverbank erosion rates at certain points can exceed one kilometer per year. The Bangladesh delta is densely populated with more than 1,000 persons per $\mathrm{km}^{2}$, doubled over the last 40 years. In this difficult environment dominated by some of the largest rivers in the world, protection of floodplain land and infrastructure from sudden river erosion has become an increasing necessity.

\subsection{Isolated riverbank protection proves insufficient}

After initial isolated attempts to protect highly valued infrastructure, Bangladesh has made great progress over the last two decades in developing sus- tainable riverbank protection. The life in the delta has a long history of riverbank protection. Initial activities, going back to the late $19^{\text {th }}$ or early $20^{\text {th }}$ century, consisted of limited protection of valuable infrastructure, such as bridge crossings or towns. An important example is the Hardinge Bridge over the Ganges which was built during the 1910s (Gales, R.R. 1917). Since the 1990s, with increasing investment into infrastructure on the floodplains, riverbank protection developed from individual, heavily protected areas into series of protective works along longer reaches of the riverbank. The development was triggered by the Flood Action Plan (Flood Plan Coordination Organization, 1995) initiated after two exceptional devastating floods in 1987 and 1988. The original concept consisted of individual "hard points" placed at some distance apart (Sir William Halcrow \& Partners Ltd. 1994, Jamuna Test Works Consultants, Joint Venture, 2001). Both approaches depended on mostly short but highly reinforced areas, and came at great cost ranging between US\$ 12 to 30 million per kilometer (at 1995 price level). However, this type of riverbank protection was characterized by frequent failures (for example Chandpur Town Protection: Sir William Halcrow \& Partners Ltd. 1990; and Sirajganj Town Protection: Team of Experts, 1998; The World Bank, 2002).

\subsection{From long-guiding revetments to river stabilization - at the dawn of the new millenium}

At the dawn of the $21^{\text {st }}$ millennium, a fundamental change occurred from individual protection towards 
longer-reach protective works, as costs per kilometer could be drastically reduced. The development was triggered by the Jamuna-Meghna River Erosion Mitigation Project (JMREMP), which developed a new low cost technology making use of Bangladesh's most abundant resources: labor and sand for placing sand bags, commonly used for emergency measures (Asian Development Bank - ADB 2002, Heibaum et.al., 2008). The design development process took place while protecting around $12 \mathrm{~km}$ of riverbank at risk of immediate erosion and consequential destruction of flood embankments protecting two large irrigation schemes. Work built in 2004 along several kilometers of riverbanks is still stable after nearly no maintenance. The design developed a number of principles to increase the stability of the work. After completing the design development process, the project increased the protective length from initially around 12 to nearly $30 \mathrm{~km}$. A newly developed Guideline for Riverbank Protection (2008) contributed to design improvements after approval in mid2010. Subsequently, other designs built on this and contributed to further improvements, namely the design of the Padma Bridge river training works (Maunsell AECOM, 2011) or the River Bank Improvement Program (Fichtner \& Northwest Hydraulic Consultants - NHC, 2015). The next section elaborates key planning and design principles.

\section{LONG-REACH PROTECTION WITH GEOTEXTILE BAG REVETMENTS}

\subsection{River stabilization through low cost revetments}

Reducing the cost from around US\$ 30 million per kilometer for Sirajganj Town Protection to around US\$ 2 million (2005 price level) allowed the protection of many kilometers of riverbanks with a stabilizing impact on the unpredictable channel pattern. The long-reach protection reduced erosion and consequently sediment intrusion between "hard points" or from unprotected banks upstream of protective works. Locally high sediment entrainment from floodplain erosion is deposited along the riverbank downstream and so increases river instability and downstream erosion risks. The stabilizing effect of $17 \mathrm{~km}$ of riverbank protection built over a length of some $20 \mathrm{~km}$ under JMREMP on the right bank channel is shown in Figure 1. The complex channel pattern in the area of the Hurasagar, with flow crossing to the left bank in 2005, was replaced by a single meandering channel in 2015. The left bank channel system (shown at the right-hand side of the figure) has not been stabilized and still consists of multiple channels.

\subsection{Adapting toe aprons to increasing scour depth}

Riverbank protection works in Bangladesh require continuous attention and adaptation at least during the first decade after construction. The reason is that riverbank protection cannot be placed down to design scour levels and depends on self-launching aprons placed on the actual riverbed levels found during construction. Design scour levels often exceed the depth that the largest cutter suction dredgers can reach (around $35 \mathrm{~m}$ ), therefore it is physically impossible to prepare man-made slopes to the design depth. In addition, dredging deep work channels along flowing channels is technically extremely difficult and comes at prohibitive cost.

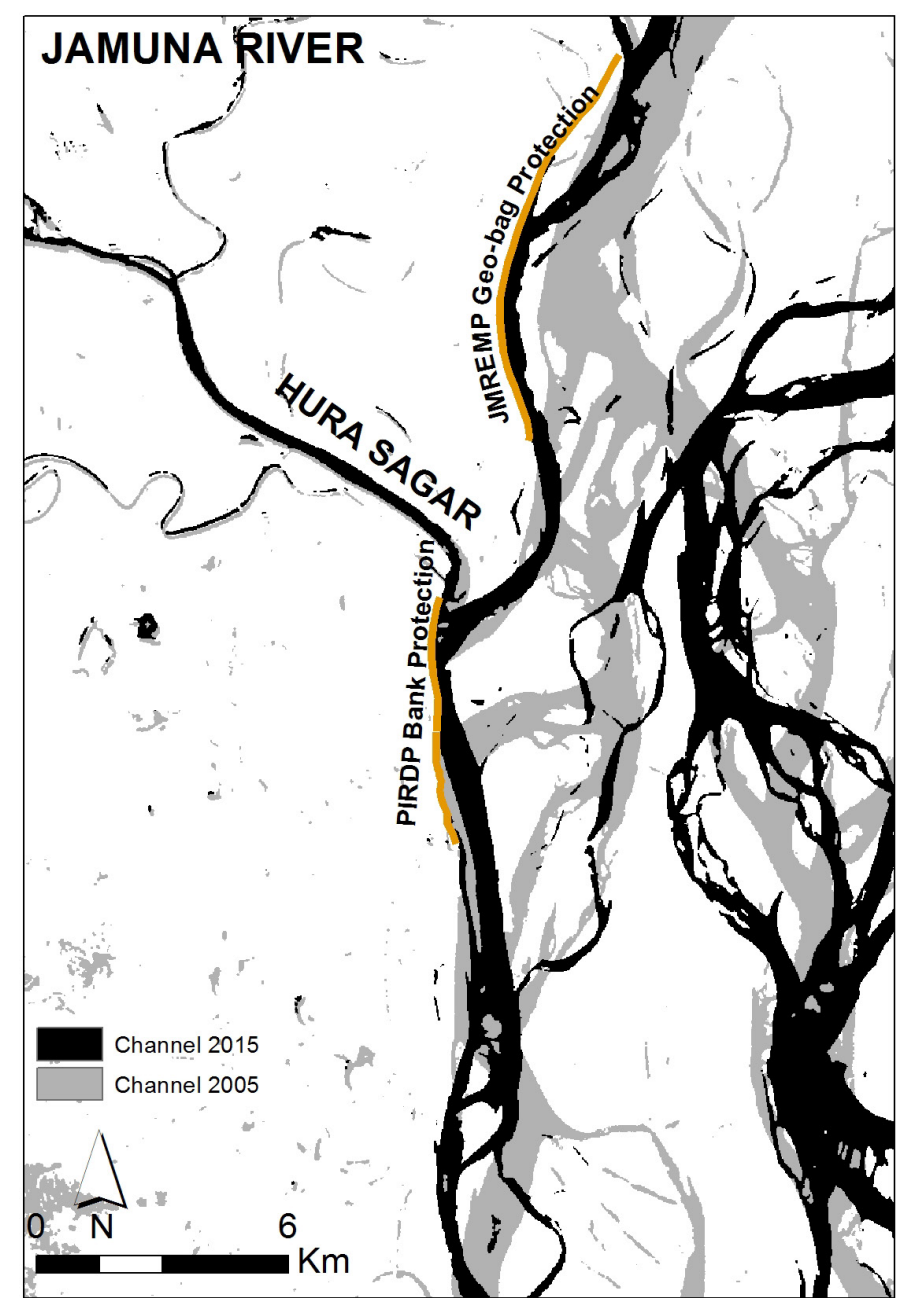

Figure 1. Stabilizing effect of riverbank protection (channel pattern 2005 compared to 2015).

Toe aprons are fundamental for the stability of the work, but their operation is still not well understood. A number of studies and publications (Thiel, 2002; Oberhagemann et al, 2008, Maunsell AECOM, 2011) provide background explaining the temporary nature of this protection and the need for adaptation to a protective thickness safe against winnowing failure. Fichtner \& NHC, 2015 conducted 3-D numerical modelling of cover layers under turbulent flow conditions, which demonstrated the fragility of launched aprons especially when consisting of hard materials like rock or concrete blocks and placed on 
tightly curved geometries, for example on upstream termination points. As a consequence of this understanding, geotextile bags of weights ranging from 78 to $900 \mathrm{~kg}$ (NHC 2006a, Maunsell AECOM 2011) have been used for aprons, due to their superior performance, providing dense coverage and an ideal filter layer for dumping additional material on top during the adaptation work. The geobags launch on a slope of $1 \mathrm{~V}: 2 \mathrm{H}$ which is at the limit state of geotechnical stability, as opposed to rock or concrete blocks which often arrive at less stable slopes of $1 \mathrm{~V}: 1.5 \mathrm{H}$ after launching.

Another aspect further defined through recent work (Maunsell AECOM, 2011, Fichtner \& NHC, 2015 ) is the fundamental influence of the underlying soil. While a $15 \mathrm{~m}$ wide apron has demonstrated good performance on consolidated soils, much wider aprons are required when placing the toe apron on unconsolidated recent deposits. At Padma Bridge aprons up to $65 \mathrm{~m}$ wide were proposed. This width acknowledges the geotechnical failure mechanism of static flow slides, during either rapid scouring or dredging. Static flow slides are triggered through unloading of the fine, granular soils, which then liquefy with consequential retrogressive failure (Figure 2) on slopes of $1 \mathrm{~V}: 3 \mathrm{H}$ or slightly flatter. Therefore toe failure triggers the geotechnical failure of the whole slope and often deep into the floodplain.

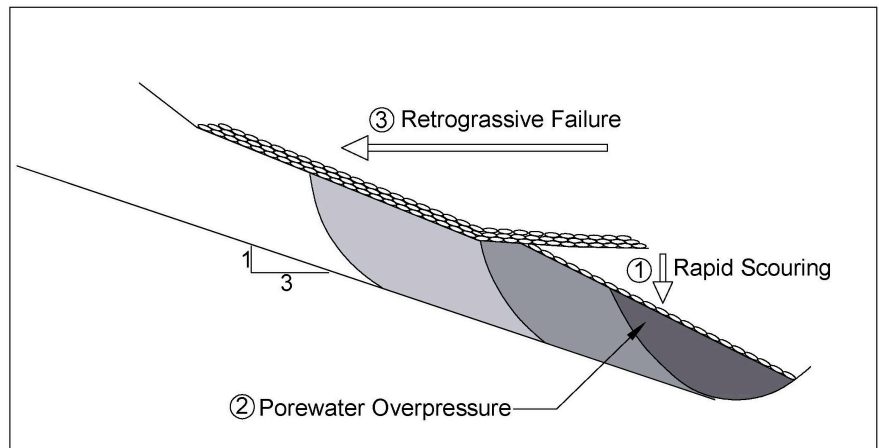

Figure 2. Retrogressive failure associated with static flow slides triggered by rapid scouring or dredging
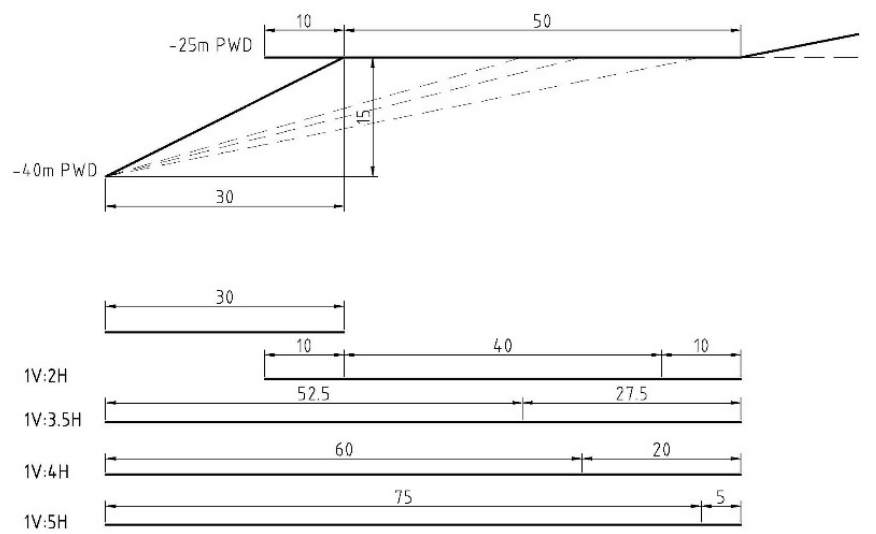

Figure 3. Concept of wide apron for different slope angles after flow slides

Consequently, a safe apron includes a width allocation to keep any static flow slide within the apron area. This prevents the whole protected slope from being destroyed (Figure 3).

As a consequence of limited launching ability and rapid scouring, protective works depends on monitoring and evaluation, adaptation and maintenance, also known as "adaptive approach" (Oberhagemann et al, 2004). The first three elements are fundamental especially during the first decade after new riverbank protection has been built when the river responds to the work and increases the depth of channels once flowing alongside unprotected riverbanks. Monitoring typically consists of river surveys with single-beam echo-sounders and diving inspection of the underwater slopes. More recently, multi-beam echosounders are used: they demonstrated that individual geobags could be seen under water during the ongoing construction of Padma Bridge. Typical adaptation work takes place when the river has deepened between 5 and $15 \mathrm{~m}$ (Maunsell AECOM, 2011). Well-adapted work is able to cope with later scouring, even though not built to final design depth. The main advantage of placing a second apron, very likely on deposited sediment covering a launched apron to some extent, is that renewed launching will result in double layer protection as explained in Figure 4.

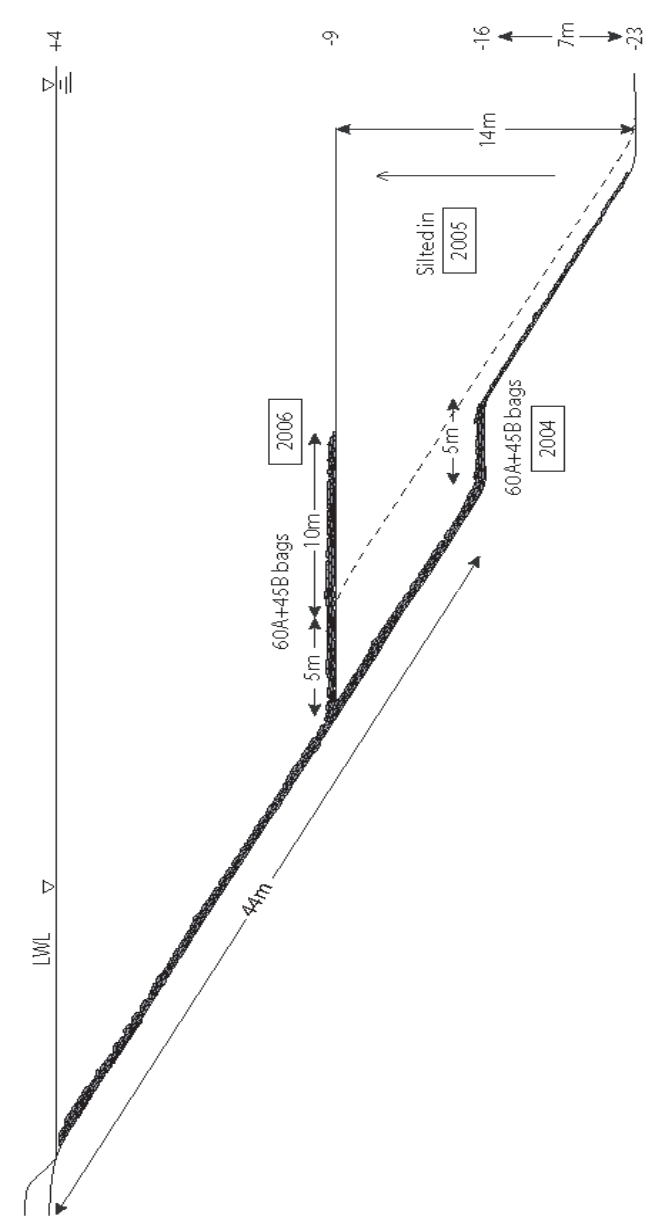

Figure 4. Example of additional launching apron placed over deeper protection that launched and then silted in (Northwest Hydraulic Consultants, 2006b). Note that $60 \mathrm{~A}+45 \mathrm{~B}$ bags refers to different weights, namely 78 and $126 \mathrm{~kg}$. 
Technical and administrative limitations, which restrict an adaptive approach to river stability, are difficult to overcome:

The technical limitations and failure mode described above require a new approach to riverbank protection work beyond a design that is based on hydraulic considerations alone and ignores the need for adaptation. Following Pilarczyk, (2000), it is necessary to consider all three interacting aspects: (i) the soil, (ii) the water, and (iii) the structure. While all three elements form part of the Guideline for Riverbank Protection (2008), the skill set of the responsible design offices have limitations, specifically in the field of geotechnical engineering and experience with modern, large-scale river training involving a broad range of river training techniques but also "building with nature" approaches (http://www.ecoshape.nl/overview-bwn.html).

Furthermore, the rigid administrative framework in Bangladesh prohibits a flexible approach in response to the rivers, despite the knowledge that: " $B W D B$ needs to adapt to what the river does, simply because the river will not adapt its behavior to $B W D B$ rules and procedures". (Brühl, H., PoE, 2005). In the past, riverbank protection was limited in length and location in Government's Development Project Proforma (DPP). However, in the extremely variable river environment the erosion location and length constantly changes, and erosion can only be predicted one year ahead, while the approval process for riverbank protection works commonly takes several years. A first improvement has been achieved in the currently implemented Flood and Riverbank Erosion Risk Management Investment Program (FRERMIP - ADB, 2014) where only the length but not the exact location was specified. The experience in $2015 / 16$ is that out of three locations, identified in early 2013 with construction starting after three flood seasons from the end of 2015, two require shorter protection, while one requires more. Further improvement will be achieved through flexible budgeting for river reaches, termed Framework DPP. Based on a first draft (BWDB, 2008), FRERMIP will develop river management strategies that incorporate flexible budgeting. Over time, river stabilization will increase the predictability and help the planning process.

\subsubsection{Geotextile stability}

The geotextile properties have not changed since the first use during large procurement contracts involving up to four million square meters of geotextile in 2003 (Oberhagemann \& Hossain, 2011). However, for longer life expectancy exceeding 30 to 50 years, such as for Padma Bridge, additional quality criteria for the geotextile fiber have been added based on accelerated aging tests (Maunsell AECOM, 2011).

\subsection{Filling and area coverage}

The implementation of geotextile bag revetments has been described in Oberhagemann et al. 2004, and Oberhagemann \& Hossain, 2007. An important aspect is the determination of the size of the geotextile bags. It is easy to translate the average specific weight of the filling sand $\left(1,500 \mathrm{~kg} / \mathrm{m}^{3}\right)$ into a theoretical fill volume, however what is needed for the design is the area one geobag covers. This is important to determine the number of bags to be dumped per linear meter of riverbank in order to achieve sufficient coverage. The "paper bag formula" from Robin (https://en.wikipedia.org/wiki/ $\mathrm{Pa}-$ per bag problem) provides a suitable means to compute the size and average thickness. The computed volume of fill can be converted into an average thickness (after placing) by accounting for the size of the geotextile bag. As rule of thumb a 125$\mathrm{kg}$ bag covers $0.5 \mathrm{~m}^{2}$ while a $250-\mathrm{kg}$ bag covers $1 \mathrm{~m}^{2}$. Field investigations with systematically placed bags confirm the theoretical findings.

The number of bags per linear meter also depends on the flow velocities. While fast flow of more than $1.5 \mathrm{~m} / \mathrm{s}$ potentially leaves some gaps even when dumping four layers, field experience indicates that three layers are sufficient, due to the commonly low velocities during the dry-season working window. Three layers are derived from the theoretical consideration that two layers of systematically placed geobags cover the slope consistently. The US Army Corps of Engineers, 1991, recommends to dump $50 \%$ more when working in flowing water, which results in three layers. Systematic diving investigations are recommended for checking and optimization of the dumping quantities in accordance to the site conditions during each dry season construction window.

\subsection{The versatile use of geotextile bags for riverbank protection}

Three uses of geotextile bags have been developed over time with increasing reliability and factors of safety:

- Emergency protection consisting of a volume of geotextile bags dumped from the riverbank for launching in response to scouring (Figure 5). This design has the lowest reliability.

- Geotextile bag revetments build through systematic dumping and adaptation of the toe apron (Figure 6). This is the standard application for long guiding revetments. The width of the toe apron determines the level of safety, ranging from small aprons with limited capacity to cover the expected scour for one season to wide aprons being able to absorb static flow slides without endangering the underwater slope.

- Filter layer under rock revetments (Figure 7). This is a special application for the highest design 
requirements implemented under difficult conditions. Presently the implementation of the river training works for the Padma Multipurpose Bridge in Bangladesh (Maunsell AECOM, 2011) makes use of this technology in places. $125-\mathrm{kg}$ geotextile bags provide the filter layer under rock coverage, as the work is done in flowing water where other types of filter layers, such as "fascine works" are difficult to place.

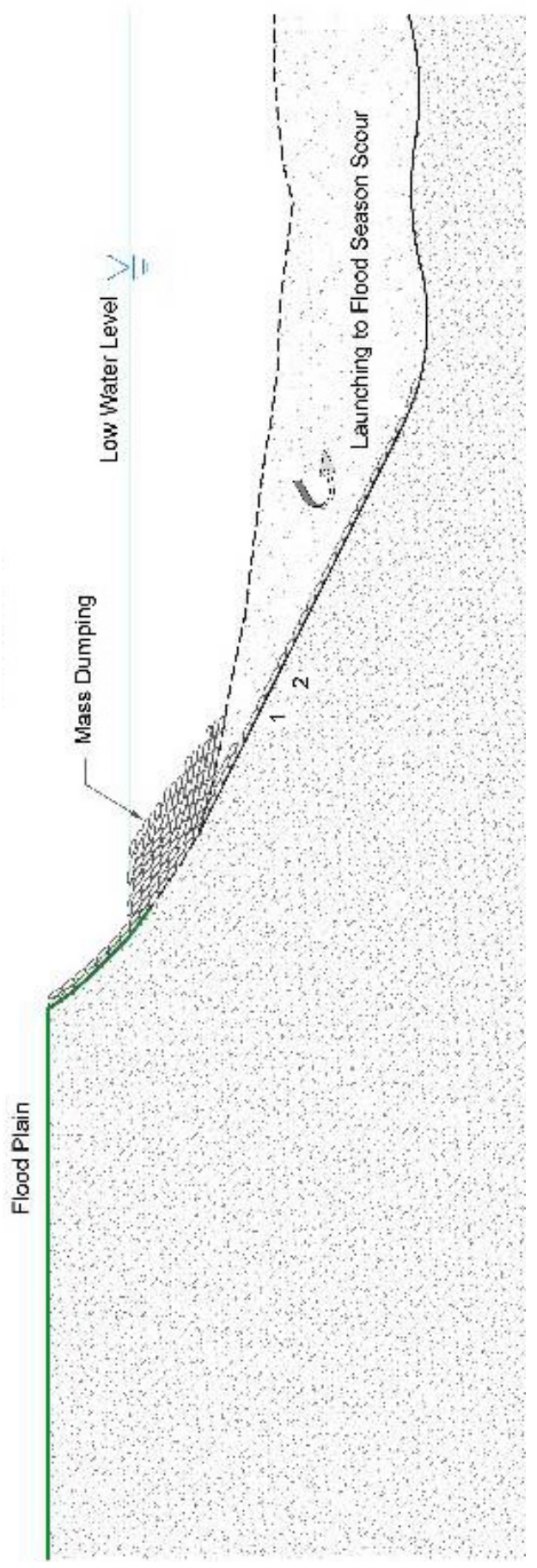

Figure 5. Emergency Protection

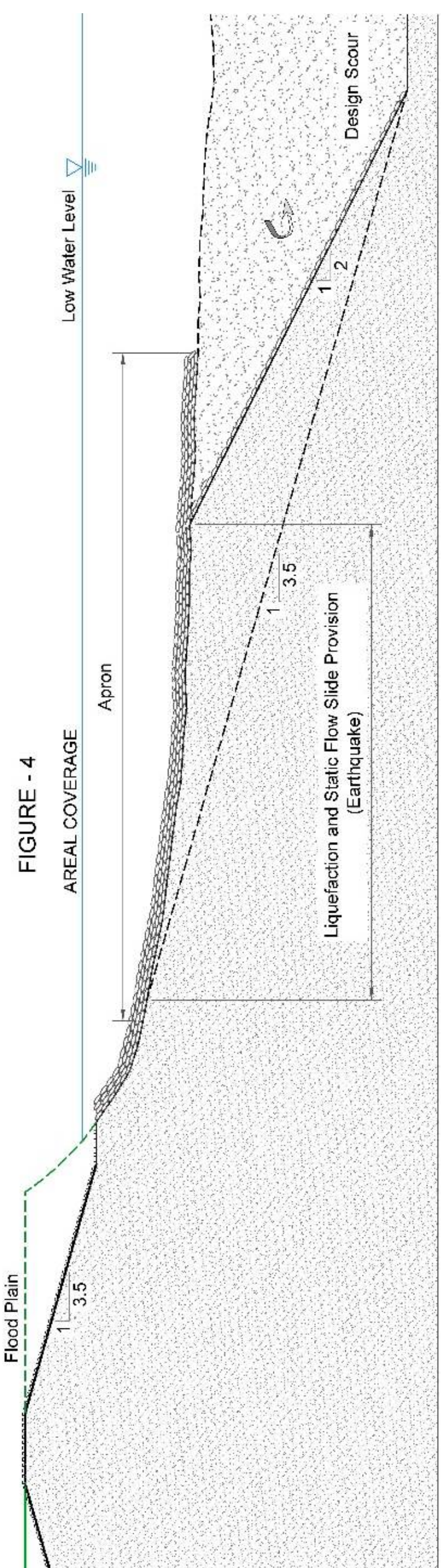

Figure 6. Geotextile bag revetments with wide apron for increased safety 


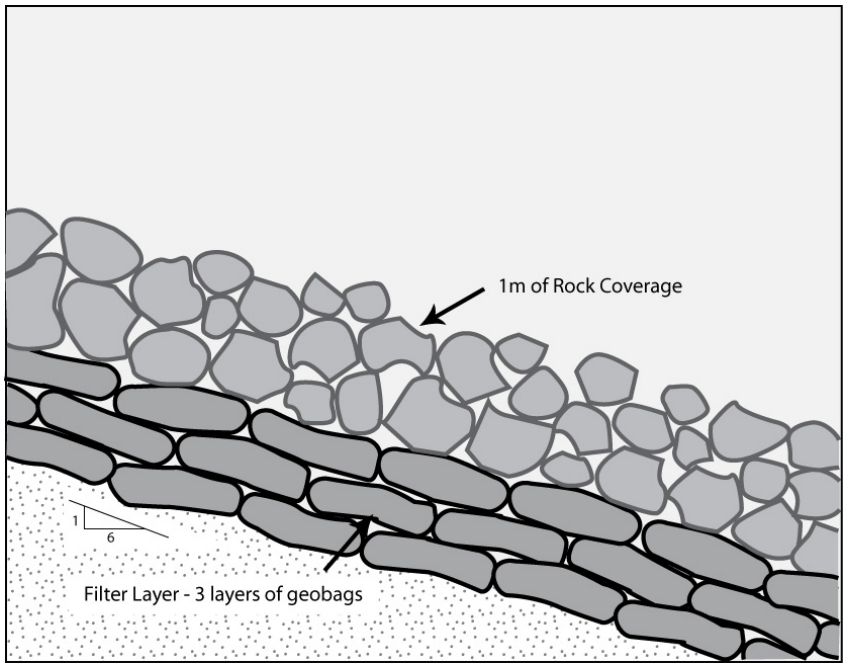

Figure 7. Rock coverage on geotextile filter layer, the example of the Padma Bridge river training works

\section{CONCLUSION AND OUTLOOK}

Two decades of intensive development of different riverbank protection alternatives on the large alluvial rivers of Bangladesh have resulted in a new technology that can sustainably protect long banklines at risk of erosion and thereby stabilize the river. This development was driven by the increasing need for riverbank protection due to the growing population and assets on the floodplains, but also the need to use local resources to a maximum extent. While the application of geotextile bag revetments has so far resulted in more than $70 \mathrm{~km}$ of riverbank protection, technical and administrative constraints yet prevent a fully flexible approach of timely reaction to river changes.

This notwithstanding, Government has moved ahead with plans to stabilize (or "channelize") the main rivers, especially the "Brahmaputra System" consisting of around $400 \mathrm{~km}$ of the Jamuna, Padma, and parts of the Lower Meghna rivers as they are named in Bangladesh. Geotextile bag revetments would be a key technology for the stabilization of outer bends in a more or less meandering river pattern.

\section{ACKNOWLEDGEMENT}

The authors like to express their gratitude to the large number of colleagues from the Bangladesh Water Development Board and national and international consulting companies who have contributed in the past and present to the continuous development of river training techniques suitable for the difficult Bangladesh environment.

\section{REFERENCES}

ADB, 2002. Report and Recommendation of the President to the Board of Directors on a Proposed Loan to the People's Republic of Bangladesh for the Jamuna-Meghna River Erosion Mitigation Project. RRP: BAN 34038.

ADB, 2014. Report and Recommendation of the President to the Board of Directors, Proposed Multitranche Financing Facility, People's Republic of Bangladesh Riverbank Erosion Risk Management Investment Program. Project Number 44167.

Brühl, Hartmut, 2005: Report of Individual Consultant (PoE), Dr. Harmut Brühl, International Riverbank Protection Management Specialist, in Jamuna-Meghna River Erosion Mitigation Project, Part C, Panel of Experts (PoE) Observations during first Mission. Prepared for the Government of the People's Republic of Bangladesh, Ministry of Water Resources, Bangladesh Water Development Board.

BWDB, 2008. Frame Work Development Project Proforma/Proposal (DPP) for River Bank Protection in the Brahmaputra/Jamuna River in Bangladesh (an Adaptation to Climate Change). Prepared by the Bangladesh Water Development Board for the Government of the People's Republic of Bangladesh, Water Resources Planning Organization

Delft Hydraulics \& Danish Hydraulic Institute, 1996. River Survey Project Final Report. Prepared for the Government of the People's Republic of Bangladesh, Water Resources Planning Organization.

Fichtner \& Northwest Hydraulic Consultants, 2015. River Bank Improvement Program, Feasibility Study and Detailed Design Phase I Priority Reach. Prepared for the Government of the People's Republic of Bangladesh, Bangladesh Water Development Board.

Flood Plan Coordination Organization, 1995: Summary Report based on Studies carried out under The Flood Action Plan. Prepared for the Government of the People's Republic of Bangladesh, Ministry of Water Resources

Gales, Robert Richard, 1917: The Hardinge Bridge over the Lower Ganges at Sara. Minutes of Proceedings of the Institution of Civil Engineers, London, Paper 4200

Guideline for Riverbank Protection, 2008. Prepared by Bureau of Research Testing and Consultancy, Bangladesh University of Engineering and Technology for the Bangladesh Water Development Board.

Heibaum, M; Oberhagemann, K; Faisal, M.A; Haque, S. Geotextile Bags for Sole Permanent Bank Protection. $4^{\text {th }}$ European Geosysnthetics Confernce, Edinburgh September 7 $10,2008$.

Jamuna Test Works Consultants, Joint Venture, 2001: Bank Protection and River Training (AFPM) Pilot Project FAP 21/22, Final Project Evaluation Report. Prepared for the Government of the People's Republic of Bangladesh, Ministry of Water Resources, Water Resources Planning Organization.

Maunsell AECOM, 2011. Padma Multipurpose Bridge Design Project, River Training Works, Final Design Report. Prepared for Bangladesh Bridge Authority by Northwest Hydraulic Consultants.

Northwest Hydraulic Consultants, 2006a. Jamuna-Meghna River Erosion Mitigation Project, Part B, Special Report 23, Design Brief for Riverbank Protection implemented under JMREMP (update). Prepared for the Government of the People's Republic of Bangladesh, Bangladesh Water Development Board

Northwest Hydraulic Consultants, 2006b. Jamuna-Meghna River Erosion Mitigation Project, Part B, Special Report 21, Site Data and Details of Work. Prepared for the Gov- 
ernment of the People's Republic of Bangladesh, Bangladesh Water Development Board

Oberhagemann, K; Stevens M.A, Haque, S.M.S, Faisal, M.A, 2004: Geobags for Riverbank Protection. 3rd International Conference on Scour and Erosion, November 1-3, Amsterdam

Oberhagemann, K, Hossain, M.M, Rashid, F, 2007. Recent Developments in Riverbank Erosion Management in Bangladesh. Rivers'07 $2^{\text {nd }}$ International Conference on Managing Rivers in the $21^{\text {st }}$ Century, Solutions Towards Sustainble River Basins, $6^{\text {th }}$ to $8^{\text {th }}$ June 2007 , Kuching, Sarawak, Malaysia.

Oberhagemann, K; Diggelmann, P, Mukhles uz zaman, 2008: Understanding Falling Aprons - Experience from the Lower Brahmaputra / Jamuna River. $4^{\text {th }}$ International Conference on Scour and Erosion, November 5-7, Tokyo

Oberhagemann, K. \& Hossain, M.M, 2011: Geotextile bag revetments for large rivers in Bangladesh. Geotextiles and Geomembranes (2010), doi: 10.1016/j.geotexmem 2010.12.003

Pilarczyk, K.W, 2000. Dikes and Revetments, Design Maintenance and Safety Assessment. A.A. Balkema

Sir William Halcrow \& Partners Ltd. 1990: World Bank (IDA) Funded Flood Damage Restoration Project, Chandpur Town Protection Design and Construction Report. Prepared for the Government of the People's Republic of Bangladesh, Bangladesh Water Development Board.

Sir William Halcrow \& Partners Ltd. 1994: River Training Studies on the Brahmaputra River, Final Report. Prepared for the Government of the People's Republic of Bangladesh, Bangladesh Water Development Board.

Team of Experts 1998. River Bank Protection Project, Brahmaputra Right Bank Priority Works, Investigation into the Damage to the Works of Contract B2 at Sirajganj during Monsoon 1998. Prepared by Team of Experts, Bureau of Research, Testing and Consultation, Bangladesh University of Engineering and Technology, Dhaka

The World Bank, 2002: Implementation Completion Report (IDA-27910; IDA27911) on a Credit in the Amount of SDR 111.2 Million (US\$ 152.0 Million Equivalent) to the People's Republic of Bangladesh for a River Bank Protection Project. Prepared by the Rural Development Sector Unit, South Asia Region

Thiel, Bettina, 2002. Behaviour of a falling apron - made from "poorly sorted" material. Thesis Delft University of Technology, Faculty of Civil Engineering and Geosciences, Department of Civil Engineering.

US Army Corps of Engineers, 1991. Hydraulic Design of Flood Control Channels, EM 1110-2-1601. 